\title{
To Study the Impact of GST on Pharmaceutical Companies with Special Reference to OTC Drugs - Retailers Perspective
}

\author{
Ayush Saraogi ${ }^{1 *}$, Ankita Singh ${ }^{1}$ and Kaustubh Sontakke ${ }^{2}$ \\ ${ }^{1}$ Post Graduate Diploma in Pharmaceutical Management, S.I.E.S College of \\ Management Studies, India \\ ${ }^{2}$ Professor of Finance and Accounting, S.I.E.S College of Management Studies, India \\ *Corresponding Author: Ayush Saraogi, Post Graduate Diploma in Pharmaceutical \\ Management, S.I.E.S College of Management Studies, Navi Mumbai, Maharashtra, \\ India.
}

Received: February 26, 2020

Published: March 11, 2020

(c) All rights are reserved by Ayush Saraogi., et al.

\begin{abstract}
Tax duty is an obligatory commitment to state income, imposed by the administration on labourers pay and business benefits, or added to the expense of certain merchandise, administrations, and exchanges. Tax is crucial to a country's economy but if there is really high taxation it will lead to a recession as manufacturers ability to produce product decreases cause of the high cost of production and reduce in numbers of buyers which indirectly impacts the overall growth of the country. Goods and Services Tax is a value-added tax which was recently implemented in India. Hence it is necessary to understand its significant impact in Indian Economy. We have done this research to find out the impact of GST application on OTC products in the Pharmaceutical sector. This study is done in order to have a better understanding of the impact of this taxation system. The research done for this study is primary base research. Set of appropriate questioners was prepared and the survey was conducted in Mumbai area. Responses were collected from the chemists in those areas. Questionnaire were prepared as per the initial equipment of the survey. We had questions based on all the major segment of OTC products like Oral Powders, Tablets, Capsules, Ointments, Creams. From this segment, we took products which are well known in the market and have good number of consumers like Electral for Oral hydration, Soframycin topical cream for bacterial infection, Evion vitamin E capsule, Volini pain relief ointment, Crocin tablets for fever and pain. From the survey, we got which of the above segment of OTC was more affected. Also, understanding of which segment i.e. OTC or Prescribe drug were more affected by the introduction of GST. Chemists views with regards to the application of GST. Impact of GST on the buying pattern of Consumer. Change in buying pattern if GST percentage is increased or decrease by a certain percentage. We also took note of how many consumers did a chemist had per day. Chemist qualification, years of experience were also taken in considerations their understanding for changes which took place is more precise and also, they have a wide spectrum of knowledge so they are aware of future consequence that may occur.
\end{abstract}

Keywords: Pharmaceutical; Tax; Drugs; Prescriptions; Regulations; Healthcare

\section{Abbreviations}

GST: Goods and Services Tax; CGST: Central Goods and Services Tax; SGST: State Goods and Services Tax; IGST: Integrated Goods and Services Tax; OTC: Over the Counter; API: Active Pharmaceutical Ingredient.

\section{Introduction}

A tax is a charge imposed by authority on persons or property for public welfare purposes (Mariam Webster). The Government needs money to maintain law and order in the country and to undertake several measures to bring the balanced growth of the state. The primary objective of collecting Tax is to generate revenue for development and welfare programs in the country. India has a welldeveloped tax structure and undergone tremendous reforms during 2017. The multiple indirect taxes have been merged into a new Good and Services Tax which was implemented from 1st July 2017. Due to GST almost 17 types of indirect taxes have been abolished making the indirect tax compliance much easier. Incorporated in 1st July 2017 by Prime Minister Mr Narendra Modi in the 101Amendment bill.

New Article 366(12A) of the Indian constitution defined good and services tax (GST) to mean any tax on supply of goods and services both except on the supply of liquor for human consumption. 366(26A) means for services while 366(12) means for goods.

Indian GST is inspired by Canadian GST system up to a large extent and broadly classified into the following types:

- CGST: It is Incorporated by the central government in order to replace central tax i.e. excise duty and services tax

- SGST: It is Incorporated by the state government in order to exclude state taxes

- IGST: IGST will be levied on all interstate supplier of goods and services and equally important that of CGST and SGST. 
The GST systems are divided into different slabs as per rates are concerned based on the types of goods and services provided. The different types of slabs include $0 \%, 5 \%, 12 \% 18 \%, 28 \%$.

Over-the-counter (OTC) drugs are medications sold straightforwardly to a purchaser without a prescription from the doctor, rather than physician recommended drugs, which might be offered distinctly to shoppers having a legitimate medicine. In numerous nations, OTC medications are chosen by an administrative organization to guarantee that they contain fixings that are sheltered and compelling when utilized without a doctor's consideration. OTC medications are typically controlled by their Active Pharmaceutical Ingredient (API) instead of a final item. By directing APIs rather than explicit medication details, governments permit producers the opportunity to plan fixings, or blends of fixings, into restrictive blends.

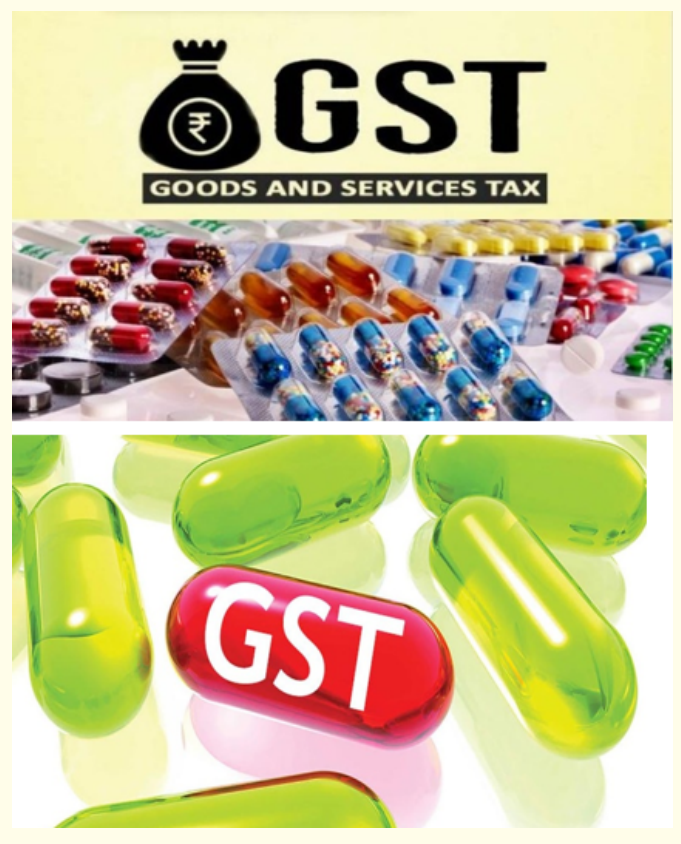

Figure 1

GST rate on some OTC product

\begin{tabular}{|c|l|}
\hline Nil & \multicolumn{1}{|c|}{ All contraceptives } \\
\hline $5 \%$ & $\begin{array}{l}\text { Oral rehydration salts } \\
\text { Medications or meds including their salts and esters and } \\
\text { indicative test packs formulations fabricated from the } \\
\text { mass medications. }\end{array}$ \\
\hline $12 \%$ & $\begin{array}{l}\text { Medicaments comprising of blended or unmixed items } \\
\text { for remedial or prophylactic uses set up in estimated } \\
\text { portions (counting those as transdermal organization } \\
\text { frameworks) or in structures or packing's for a retail } \\
\text { deal, including Ayurvedic, Unani, homoeopathic Siddha } \\
\text { or Biochemical frameworks medicaments, set up for a } \\
\text { retail deal. } \\
\text { Wadding, cloth, swathes and comparable articles (for } \\
\text { instance, dressings, cement mortars, poultices), impreg- } \\
\text { nated or covered with pharmaceutical substances. }\end{array}$ \\
\hline $18 \%$ & Nicotine polacrilex gum \\
\hline
\end{tabular}

Table 1

\section{Research Methodology/Material and Methods}

Research is conducted in Mumbai city. Primary data is collected in the research with the help of the questionnaire and also understand the effect by interviewing retailers.

The sample size taken was 20 retailers.

\section{Questionnaire}

Survey

- Name of Shop

- Qualifications

- Years of Experience

- Number of Consumer per day

- Which segment is mostly affected by GST as per you: OTC/ Prescribe drugs

- Did GST affect the frequency of OTC drug sold: Yes or No

- Did effect occur increased or decreased the frequency of selling?

- Did you see any effect on these products after implementation of GST?

\section{- Products}

- Electral - Oral rehydration: 1 to 5

- Soframycin - skin: 1 to 5

- Evion - multivitamin: 1 to 5

- Volini - pain reliever: 1 to 5

- Crocin - analgesic: 1 to 5

- Rate each on the scale of 5 as per the effect of GST on that particular product

- 1 for least effected

- 5 for highly effected

- If the price of OTC drug increases by $5 \%$ will consumer still prefer it?

- Rate GST as per your satisfaction:

- 1 for Highly Dissatisfied

- 5 for Highly Satisfied

\section{- Objectives}

- To find the impact of GST on selling of OTC drugs.

- To find the retailers Perspectives on it.

\section{- Limitations}

- Study only GST impact.

- Limited to Indian pharmaceutical companies.

- Limited to an area of Mumbai.

\section{Results and Discussions}

The research conducted include majority of Diploma in pharmacy graduate i.e. $43 \%$ followed by Bachelors of pharmacy graduate i.e. $33 \%$ and the Masters of pharmacy graduates i.e. $24 \%$ and most 
of the retails having experience in retail shop of between five to ten year so than they have seen the effect a before and after implementation of GST.

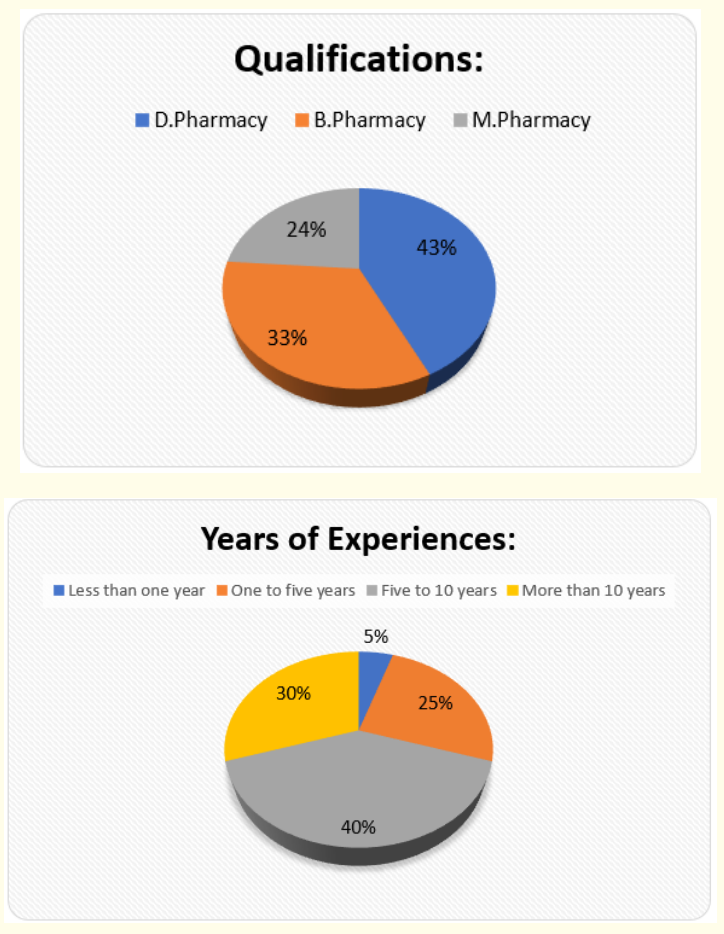

Figure 2

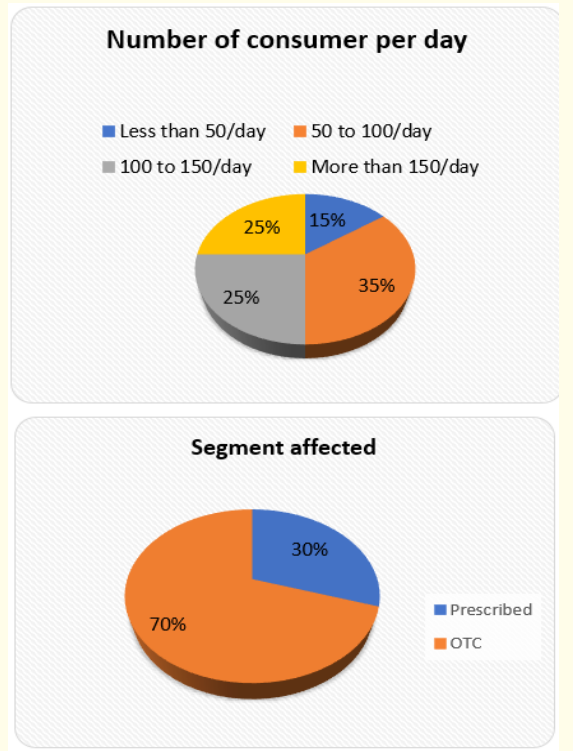

Figure 3

According to them, the segment which is mostly affected by GST is the OTC segment, not a drug which is prescribed by the physicians and also its decreased the frequency OTC drugs sold by the retailers.

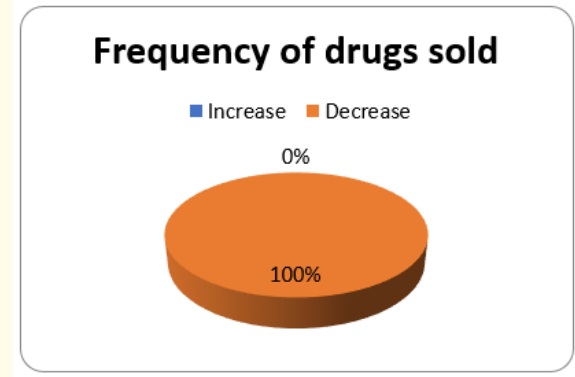

Figure 4

Product categories and the effect of GST on them

Rate each on the scale of 5 as per the effect of GST on that particular product.

- $\quad$ One for least effected

- $\quad$ Five for highly effected

Electral - oral rehydration

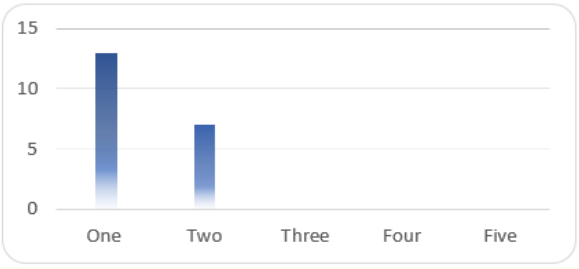

Figure 5

Dehydration is a common problem for all of us and also the consumption of these products are frequent as compared to others. Study on this clearly indicates it is one of the least affected product. Thirteen were said one (least affected) and seven went for two which means it is one of the unaffected segment after GST.

Soframycin - skin

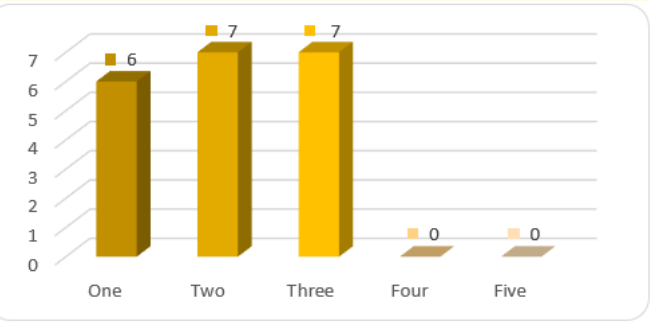

Figure 6

Derma is one of the fastest growing sector in Indian pharmaceutical market and to hence any change in this segment is essential for us to take care of even taxation system also So out of twenty responses that we collected six were said its is least affected while 
seven gave two and other seven gave three ratings as per the effect of GST on it. So it is clearly indicated that GST does not have a major impact on this segment of OTC products.

Evion - multivitamin

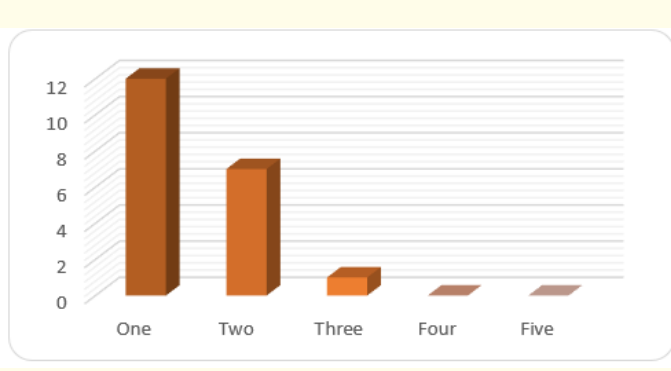

Figure 7

Multivitamins are used in various indications and also with combinations with many drugs and its consumption has now become quite common to all of us and from the above data, it is clearly indicated how GST influence the consumption of multivitamins majority of said it is not affected much by GST while few were with that it is effected but at very low level.

Volini - pain reliever

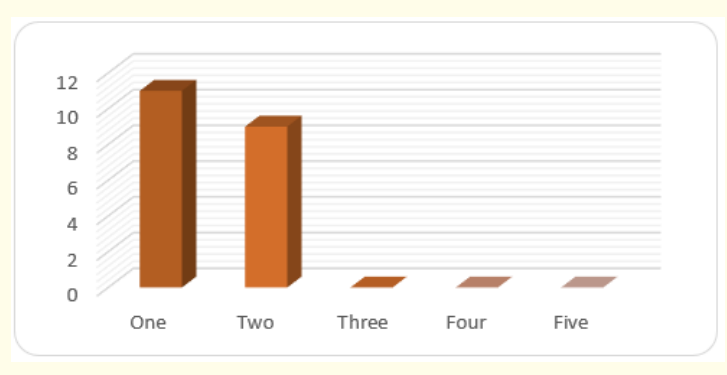

Figure 8

We all have experienced the pain at least once in our lives and we all are aware of these pain reliever products specially volini. The survey itself indicates that GST does not reflect much effects on volini.

Crocin - analgesic

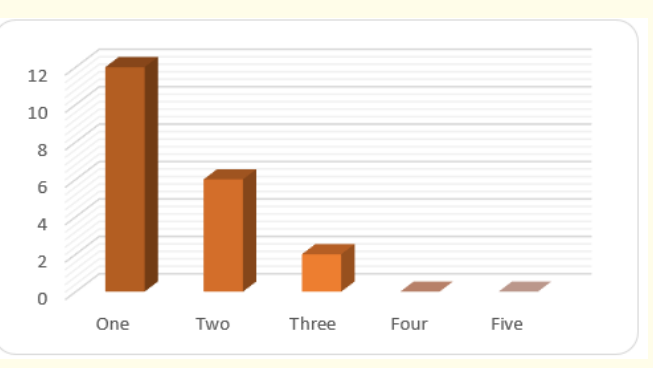

Figure 9

Analgesics are also playing an important role in our life. We all are aware of paracetamol which is used for reducing fever. As our day-to-day lifestyle becomes more hectic it is role is increasing day by day So it is important to know how GST impacted its selling and findings clearly say that it is least affected as twelve were gone for one rating, followed by Six for two rating and only two gave three.

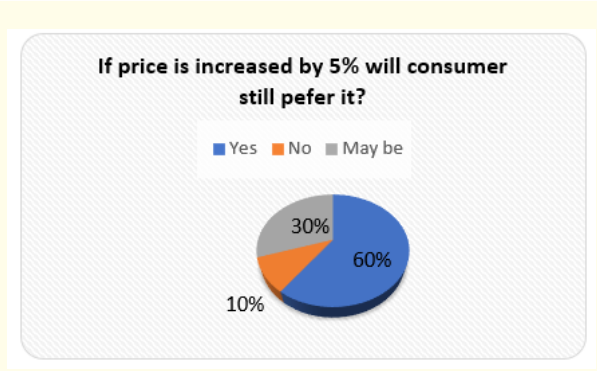

Figure 10

It holds true that GST has decreased the frequency of selling but also most the retailers still believe that if the price will increase by $5 \%$ of buyers will still go for these products.

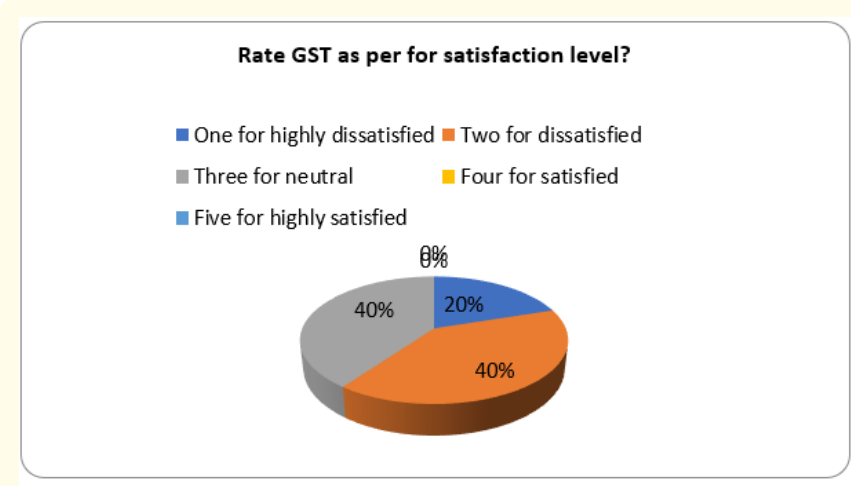

Figure 11

It is last and most important question that what they feel about GST implementation on OTC drug and Only 20\% are highly dissatisfied with GST While $40 \%$ said there are not highly but somewhere not happy with GST and another 40\% take neutral stands [1-3].

\section{Conclusion}

As it is rightly indicated that any changes in the tax system should impact sales and buying, so it does with GST. Survey clearly shows that GST has affected the selling of OTC product though the impact is seen at a very minimal level, which hasn't affected much in selling and buying of OTC products. The study will be more of interest to business entrepreneurs as the topic was on value-added tax. However, wholesale and retail pharmacists may also be interested because OTC medications were the subject matter.

\section{Acknowledgment}

My sincere thanks to my college colleagues, faculty and management for their support.

\section{Conflict of Interest}

The author declares no conflict of interest. 


\section{Bibliography}

1. GST for the layman by Vishal Thakkar.

2. V Kinjal., et al. "Impact of GST Pharmaceuticals: An overview". Open Journal of Pharmaceutical Research 2.2 (2018).

3. Md. Yaqub Khan., et al. "Review on Marketing of OTC Drugs". Journal of Scientific and Innovative Research 3.2 (2013).

\section{Assets from publication with us}

- Prompt Acknowledgement after receiving the article

- Thorough Double blinded peer review

- Rapid Publication

- Issue of Publication Certificate

- High visibility of your Published work

Website: www.actascientific.com/

Submit Article: www.actascientific.com/submission.php

Email us: editor@actascientific.com

Contact us: +919182824667 